\title{
ATTITUDINAL MEANING IN COVID-19 LOCAL LANGUAGE GUIDELINES OF INDONESIA: A SYSTEMIC FUNCTIONAL LINGUISTIC STUDY
}

Makna Sikap dalam Pedoman Bahasa Daerah terkait COVID-19 di Indonesia: Kajian Linguistik Sistemik Fungsional

\author{
Dini Sri Istiningdias, Lia Maulia Indrayani, Eva Tuckyta Sari Sujatna, dan Wagiati \\ Universitas Padjadjaran \\ Jalan Raya Bandung Sumedang KM.21, Jatinangor, Jawa Barat, Indonesia \\ dini19006@mail.unpad.ac.id
}

Naskah Diterima Tanggal 25 Februari 2021 - Direvisi Akhir Tanggal 9 September 2021 — Disetujui Tanggal 1 December 2021 doi: https://doi.org/10.26499/rnh.v10i2.2243

\begin{abstract}
Abstrak
Kementerian Pendidikan dan Kebudayaan telah menerbitkan pedoman perubahan perilaku protokol kesehatan 3M terkait kampanye pencegahan penularan COVID-19 dalam 77 bahasa daerah di Indonesia. Namun, penelitian ini hanya berfokus pada pedoman yang menggunakan Bahasa Sunda sebagai bahasa daerah di Jawa Barat. Penelitian ini bertujuan untuk mengidentifikasi jenis-jenis sikap dan menganalisis makna yang muncul dalam pedoman tersebut. Penulis menggunakan teori Martin and White (2005) yaitu subsistem sikap sebagai bagian dari sistem penilaian dengan pendekatan Linguistik Sistemik Fungsional yang menunjukkan sikap evaluatif penulis terhadap berbagai hal yang ditulis untuk mengarahkan pembaca. Hasil penelitian menunjukkan bahwa beberapa informasi mengandung penilaian baik sisi positif maupun negatif seperti, penulis menemukan 15 klausa yang termasuk dalam indikator afektif subsistem sikap bermakna keamanan dan 4 klausa bermakna kepuasan. Selain itu, penulis menemukan 16 klausa yang termasuk dalam subsistem sikap indikator penilaian yang mengacu pada penghargaan sosial dan 3 klausa yang mengacu pada sanksi sosial. Penulis juga menemukan 12 klausa yang termasuk dalam subsistem sikap indikator apresiasi mengacu pada komposisi, 5 klausa mengacu pada penilaian, dan 2 klausa mengacu pada reaksi. Berdasarkan hasil analisis dari setiap klausa yang tercantum dalam pedoman perubahan perilaku protokol kesehatan 3M maka penulis menyimpulkan bahwa pesan yang disampaikan bermakna sikap positif bagi masyarakat.
\end{abstract}

Kata-kata Kunci: sistem evaluasi bahasa, sikap, pedoman COVID-19, fungsional, bahasa daerah

\begin{abstract}
The Ministry of Education and Culture has published 3M's health protocol behavior change guidelines regarding the campaign to prevent COVID-19 transmission in 77 local languages of Indonesia. However, this research only focused on guidelines that used Sundanese as a local language in West Java. This research aimed to identify the types of attitudes and analyze the meanings that appear in these guidelines. The author used the theory of Martin and White (2005), namely the attitude subsystem as part of the appraisal system with Systemic Functional Linguistic approach which showed the author's evaluative attitude towards various things written to lead the readers. The result of this research showed that some information contained judgement both positive and negative side such as the authors found 15 clauses included in the affective indicator of the attitude subsystem in security meaning and four clauses satisfaction meaning. In addition, the authors found 16 clauses included in the attitude subsystem of judgment indicator referring to social esteem and three clauses referring to social sanction. The author also found 12 clauses included in the attitude subsystem of appreciation indicator referring to composition, five clauses referring to valuation, and two clauses referring to reaction. Based on the
\end{abstract}


results of the analysis of each clause listed in the $3 M$ health protocol behavioral change guidelines then the authors conclude that the message conveyed is positive attitude for the society.

Keywords: appraisal system, attitude, COVID-19 guidelines, functional, local language

How to Cite: Istiningdias, Dini Sri, dkk. (2021). Makna Sikap dalam Pedoman Bahasa Daerah Terkait Covid-19 di Indonesia: Kajian Linguistik Sistemik Fungsional. Ranah: Jurnal Kajian Bahasa. 10(2). 240-251. doi: https://doi.org/10.26499/rnh.v10i2.2243

\section{INTRODUCTION}

The first case of COVID-19 was found in Wuhan, China in December 2019. Over time, the Corona virus has infected around 90,308 people as of March 2, 2020, while the number of deaths has reached 3,087 people or around 6\%. The source of this virus came from animals, especially bats, bamboo rats, and civets (Yuliana, 2020). Meanwhile, WHO (2020) stated that the spread of the Corona virus was growing rapidly. This is evidenced by the spread of the virus which has spread almost all over the world, including Indonesia. The Indonesian government followed the direction of the WHO to handle the spread of Covid-19 in the form of implementing social distancing and then changing the term to physical distancing. During the implementation of the policy, the public is advised to stay away from physical contact between one person and another, always stay at home, avoid crowds, always wash their hands, and always wear a mask. Corona Virus Disease 2019 is an infectious disease caused by a new type of coronavirus. According to WHO (2020) based on Global Surveillance guidelines, the definition of COVID-19 can be classified into three parts, namely: (1) suspected cases or suspected cases, (2) probable or probable cases, and (3) confirmed cases or patients who have been diagnosed with COVID-19. tested positive through laboratory tests. While in Indonesia the definition of the classification of COVID-19 cases is divided into: (1) patients under surveillance or PdP, (2) people under monitoring or OdP, and (3) people without symptoms or OTG (Kemenkes RI, 2020).

The variety of health terms in handling the spread and transmission of Covid-19 in Indonesia gave a socio-cultural impact such as a collision or the negative or positive influences in people's lives. The lack of understanding of some Indonesian people on the function of each health term conveyed by the government represented by the Ministry of Health and the Covid19 Handling Task Force has triggered a clash in the socio-cultural field. Based on this, the government carried out various outreach strategies to the society, one of which was the launch of " The Behaviour Change of 3M Health Protocols in 77 Local Language Covid-19 Guidelines" on December 2020 by the Language Development and Management of the Education and Culture Ministry in collaboration with the Health Ministry and the Indonesian Disaster Management National Agency. This guideline is based on an article sent by the Covid19 Task Force Team. The guidelines contained messages which conveyed by the government through a campaign to prevent the spread of Covid-19 with the purpose of making it easier to understand and implement in people's daily lives.

Meanwhile, the various restrictions did not give a significant impact on reducing the number of patients and even the development of the spread of Covid-19 is getting out of control in 2021, especially on Java and Bali islands. This is the basis for the Indonesian government to implement a stricter area restriction program apart from previous programs such as 1) PSBB for the April-June 2020 period; 2) Transitional PSBB for the period June-September 2020; 3) Strict PSBB for the period September-October 2020; 4) The $2^{\text {nd }}$ PSBB Transition for the period October 2020-January 2021; 5) PPKM period January-February 2021; and 6) Micro PPKM for the period February-June 2021. The Indonesian government is still trying to continue the regional restriction program specifically on Java and Bali islands such as Emergency PPKM for the period 1-20 July 2021 and PPKM $3^{\text {rd }} \& 4^{\text {th }}$ Level for the period 21-25 July 2021. Based 
on developments under these conditions, the authors are interested in analyzing the "The Behaviour Change of 3M Health Protocols in 77 Local Language Covid-19 Guidelines"' which is limited to the focus of the research only referring to West Java Province as part of Java Island which has experienced an increase in Covid-19 cases. This research aimed to identify the types of attitudes and meanings that appeared in Sundanese Covid-19 guidelines. The author used the theory of Martin and White (2005), namely the attitude subsystem as part of the appraisal system with a Functional Systemic Linguistic approach which showed the author's evaluative attitude towards various things written to direct the reader.

\section{THEORETICAL BASIS}

\section{Covid-19 in Indonesia}

The whole world is battling the outbreak of the Coronavirus Disease-19 (COVID-19). The main source emerged from the city of Wuhan, in particular the Huanan Seafood Market which is known as a center for selling exotic foods so that it is thought to have come from bats or pangolins. Meanwhile, WHO has declared COVID -19 as a public health emergency of international concern on January 30 (Dong et al., 2020). The addition of the number of COVID -19 cases took place quite quickly and spread between countries such as in Indonesia it was reported that there were a total of 414,179 confirmed cases with 18,440 deaths (CFR 4.4\%) based on cases in 192 countries/regions in Indonesia as of March 25, 2020 In addition, there were several health workers who were reported to be infected (Kemenkes RI, 2020).

On March 12, 2020, WHO declared Covid-19 a pandemic. The number of cases in Indonesia continued to increase rapidly until June 2020 as many as 31,186 confirmed cases and 1851 cases died (PHEOC Ministry of Health RI, 2020). WHO issued six priority strategies that the government must carry out in dealing with the Covid-19 pandemic on March 26. The strategy consisted of expanding, training and laying down health care workers; implement a system for suspected cases; increase test production and improve health services; identification of facilities that can be converted into coronavirus health centers; develop a plan for quarantining cases; and refocusing government measures to suppress the virus (WHO, 2020).

A research published by Djalante (2020:3) discussed Indonesia's response to the Covid19 pandemic phenomenon. The study stated that at the end of March 2020, the Task Force for the Acceleration of Handling COVID-19 issued Guidelines for Rapid Medical Response and Public Health Aspects of COVID-19 in Indonesia. The guide provided medical personnel and the general public with ways to reduce impact and mortality rates. Information included protocols for rapid testing using RDT, laboratory testing, patient management, and outreach/communication tools. Protocols for rapid testing and lab testing recognized three levels of risk: asymptomatic (asymptomatic), Person Under Monitoring (ODP), and Patient Under Surveillance (PDP). In addition, Indonesia has implemented border closures and entry restrictions, Large-Scale Social Restrictions (PSBB) and a ban on going home (Caraka, 2020).

\section{Health Protocol Behavior Change Guidelines}

The Behaviour Change of 3M Health Protocols in 77 Local Language COVID-19 Guidelines published by the Language Development and Management of the Education and Culture Ministry in collaboration with the Health Ministry and the Indonesian Disaster Management National Agency were one of the strategies to make it easier for the public to understand terms related to the COVID-19 pandemic. The guidelines contained health protocols that need to be carried out by the society in daily life such as wearing masks, washing hands, and maintaining distance. The Indonesian government seeks to control communication barriers and public outreach so that clean and healthy living habits can be implemented gradually in accordance with health protocol guidelines so as to help reduce cases affected by COVID-19. 
The message contained in the $3 \mathrm{M}$ health protocol behavior change guidelines was a strategy that needs to be implemented on an ongoing basis because Indonesia's COVID-19 cases have increased since June 2021. An indication of the increase cases is that the understanding of the Indonesian people towards the implementation of health protocols has not been optimal. Some people still did not wear masks, did not wash their hands, and even crowd without keeping their distance. Therefore, the behaviour change of $3 \mathrm{M}$ health protocols in 77 local language COVID19 guidelines still required more specific socialization actions to each society circle so that it became a new habit that is more adaptive. The success of the behavior change program can be measured by the decrease in the number of infected cases and the increased compliance and discipline of the $3 \mathrm{M}$ protocol (covid19.go.id) based on the following indicators:

a. Individu: increasing the percentage of $3 \mathrm{M}$ compliant individuals.

b. Family: increasing percentage of $3 \mathrm{M}$ compliant family members.

c. Community: decrease in activities that cause crowds and disobey $3 \mathrm{M}$

d. Institution: the increasing number of institutions that have rules and implement COVID19 prevention protocols and provide facilities that support 3M compliant people

e. Region/Society: a decrease in the percentage of citizens who believe they will not be infected with COVID-19.

\section{Systemic Functional Linguistic}

Systemic Functional Linguistics (SFL) was a linguistic branch which introduced by Halliday in the early 1960s. (Wiratno, 2018) said that SFL was a linguistic study that discussed how to choose language forms in the context of using language as text. In other words, SFL saw language as a communication system and analyzed grammatical structures to find ways in which speakers and writers exchange meaning. Halliday \& Matthiessen (2004) described that SFL was a broad term that included various types of analysis, including expression analysis (phonetics and phonology), content analysis (lexicogrammatical and semantic) and context analysis. Context was a very important issue because it contributed significantly to the process of making meaning. One person cannot speak and write in isolated clauses but in meaningful units called texts and influenced by context. The focus of SFL studies lied in the suitability of a form for certain communicative purposes in certain contexts. In addition, (Fontaine, 2013) revealed that anyone who has tried to communicate with someone in an unfamiliar language or with a two-year-old will know that being grammatically correct is almost irrelevant. Based on this, SFL related into communication systems and analyzed grammatical structures so that they had functions and produced meaning.

In analyzing a text, one person must start with its context and type (register and genre). These aspects were closely related to three contextual variables, namely: field (topic being discussed), tenor (participant relationship) and mode (communication channel). These variables explained how individual language use is highly function dependent. Meanwhile, Halliday \& Matthiessen (2004) introduced a dimension called language metafunction, which consists of ideational, interpersonal, and textual components. The ideational metafunction refered to the ability of language to interpret human experience into categories (experiential) and further configure them into complex (logical) patterns. This metafunction is largely concerned with the use of transitivity, which included three main elements: process, participant and circumstantial; and ideational metaphors. Interpersonal metafunction embodied the ability of language to negotiate social roles and attitudes. It can be analyzed through the use of modes, modalities, and speech acts as well as interpersonal metaphors. Textual metafunction was the ability of language to create discourses that involve themes and rhymes, as well as the use of cohesive devices both at the lexical and grammatical levels. 


\section{Appraisal System}

The emergence of the appraisal system theory is due to the lack of sharp interpersonal meaning analysis conducted in Systemic Functional Linguistics (SFL). The analysis of interpersonal meaning is limited to descriptive only in the division of mode and residue where the mode consisted of a subject and a finite verb, while residues are other elements in the clause outside the mode (Martin, J.R. and Rose, 2003). (Martin, 2005) asserted that the presence of an appraisal system can describe how evaluation is established, strengthened, targeted, and sourced. The appraisal framework is an extension of interpersonal function of SFL which concentrates on how evaluative acts and the language of evaluation can be taken into account when making an analysis of the texts and social contexts in use (Don, 2021). The apppraisal system articulated interpersonal meaning with two other systems, namely negotiation and involvement. Negotiation complemented the appraisal system by focusing on the interactive aspects of discourse, the function of speech and the structure of exchange. Involvement complemented the appraisal system by focusing on non-staged resources for negotiating tenor relationships, particularly solidarity. Based on that, (Ross and David, 2019) in the research results showed that Donald Trump's political tactics are realized linguistically by applying an appraisal framework. In addition, the appraisal system is divided into three domains, namely engagement, attitude, and graduation (Martin, 2005). The author only focused this research on indicators of the attitude subsystem.

The attitude subsystem refered to the types of phrases used, including adjectives and adverbs that showed the writer's/speaker's evaluative attitude towards what is written or spoken in order to lead the reader/listener. The attitude subsystem covers meanings by which positive or negative assessments are conveyed or activated - meanings by which addressees are positioned to favourably or unfavourably view participants, processes or situations. This attitudinal positioning may be undertaken via the use of explicitly positive or negative lexis (term 'inscription') or via implication, suggestion, or association (term 'invocation) (Zaidi, A., 2021). An example of exploring the distribution of attitude systems towards public trust and national solidarity is found in the research conducted by (DING, 2017) in Obama's victory speech. The attitude subsystem is divided into three, namely affect, judgment, and appreciation. In addition, (Bloom, K. \& Argamon, 2010) reveal that affect is related to emotional expression (happy, sad, angry, etc.); judgement focuses on the character and behavior of the individual (he is bad, he is good, he is brave, etc.); and appreciation of evaluating objects (amazing sunsets, beautiful pictures, etc.). Affect is an emotional response to a verb which is usually realized by mental verbs, namely hate, love, adore, think; and relational verbs as in the clause He is happy or in the grammatical metaphor The happiness comes upon him. Based on this, (Martin, 2005) stated that affect is related to awareness of positive and negative feelings: do we feel happy or sad, confident or anxious, interested or bored? In addition, affect intersects with emotions, reactions to behavior, texts/processes, and phenomena. (Martin, 2005) classified the meaning of affect into 3 types, namely "happiness" (un/happiness), "security" (in/security), and "satisfaction" (dis/satisfaction).

The meaning of "happiness" (un/happiness) involved feelings of pleasure or sadness, and may direct these feelings as triggers in terms of liking or disliking. The meaning of "happiness" (un/happiness) included emotions related to matters of the heart such as sadness, hatred, happiness, and love. The meaning of "security" (in/security) related to feelings of peace and restlessness regarding the environment, including people who share those feelings with others. The meaning of "security" (in/security) included emotions related to ecosocial well-being such as anxiety, fear, self-confidence, and trust. The meaning of "dis/satisfaction" related to feelings of accomplishment and self-frustration towards the activities in which we are involved, including our roles as participants and spectators. The meaning of "satisfaction" 
(dis/satisfaction) included emotions related to the achievement of goals such as feelings of boredom, displeasure, curiosity, and respect.

Judgement carried meaning that interpreted our attitudes towards people and the way they behave through character measurements. Based on this, (Martin, 2005) stated that judgment is related to resources for assessing behavior according to various normative principles. In addition, judgment intersected with attitudes toward behavior that we admire or criticize, praise or condemn. Halliday (1994) classified judgments based on modality, while (Martin, 2005) classified judgments based on two things, namely social esteem and social sanctions.

Judgement of esteem must be done with 'normality' (how unusual a person is to face reality or destiny) indicated by modalities such as normal, average, fashionable, typical, odd; 'capacity' (how capable they are in each authority) is indicated by modalities such as healthy enough, mature enough, smart enough; 'tenacity' (how firmly they solve problems) is indicated by modalities such as firm, steadfast, hard-hearted, and persistent. Social rewards tend to be respected in oral culture, through chatter, gossip, jokes, and stories of various kinds with humor often having an important role to play.

Judgement of sanctions must be carried out with 'honesty' (how honest a person is in revealing the truth) indicated by modalities such as true, honest, credible, genuine, false) and 'politeness' (how ethical a person shows politeness) is indicated by this modality. such as corrupt, insensitive, arrogant, selfish, rude. Social sanctions are more often codified in writing, such as fatwas, decrees, rules, regulations, and laws on how to behave as leverage against those who do not comply with the code.

In general, appreciation can be divided into our 'reaction' to things (do they catch our attention; do they please us?), their 'composition' (balance and complexity), and their 'value' (how innovative, original, timely, etc). (Eggins, 2004) in (Martin, 2005) explained that appreciation is related to mental processes (the way we look at things) through reaction, composition and valuation (reaction, composition, and valuation). Affection-related reactions are emotive - 'it grips me' or desiderative - 'I want it'. Composition is related to perception, such as how we view things. Assessment is related to cognition such as considering opinions. With appreciation, we turn to meanings that limit our evaluation of things. Everything we do and show or what we give includes what natural phenomena are of value (the way we judge things).

\section{RESEARCH METHOD}

This research used a descriptive method with a qualitative approach. Bogdan and Taylor in (Moleong, 2002) stated that qualitative research methods have research procedures that produced descriptive data in the form of spoken words, writing and pictures and not numbers from people and observable behavior, this approach is directed at the background and the individual as a whole. This research was conducted to explore the meaning of an object, that research is an activity aimed at knowing the ins and outs of something. The intricacies explored in this study are the types of attitude subsystems used in the 3M's health protocol behavior change guidelines regarding the campaign to prevent COVID-19 transmission in 77 local languages of Indonesia by using data from words, clauses or quotes through an appraisal perspective as a language evaluation system.

The technique used in this research is technical content analysis. Content analysis was the most common and abstract qualitative data analysis technique. This technique included efforts to classify symbols used to communicate using criteria in classification, and used certain analytical techniques in making predictions. Therefore, it took a research instrument in tabular form to facilitate the classification process that the instrument was a tool used at the time of research through a method. 


\section{DISCUSSION}

\section{Affect}

The author choose data in Sundanese language from West Java Province. Sundanese is one of the regional languages which included in the $3 \mathrm{M}$ health protocol behavior change guidelines in Indonesia. This guideline contained the affective subsystem as messages. Affect related to awareness of positive and negative feelings included 3 types of meaning, namely "happiness" (un/happiness), "security" (in/security), and "satisfaction" (dis/satisfaction). The author classified the research data according to the meaning indicators in the table below:

\begin{tabular}{|c|c|c|c|}
\hline \multirow{2}{*}{ Clauses } & \multicolumn{3}{|c|}{ Affect } \\
\hline & Un/Happiness & In/Security & Dis/Satisfaction \\
\hline Sing apal ka diri sorangan & - & $\sqrt{ }$ & - \\
\hline Sing apal ka musuh anjeun & - & $\sqrt{ }$ & - \\
\hline Sing apal kana medan perang anjeun & - & $\sqrt{ }$ & - \\
\hline Ngungkulan Covid-19 & - & - & $\sqrt{ }$ \\
\hline Mikanyaah diri sorangan & - & - & $\sqrt{ }$ \\
\hline Mikanyaah batur & - & - & $\sqrt{ }$ \\
\hline $\begin{array}{l}\text { Ku cara paanggang, urang bisa ngurangan } \\
\text { risiko katepaan }\end{array}$ & - & - & $\sqrt{ }$ \\
\hline $\begin{array}{l}\text { Ulah padeukeut jeung saha wae } \\
\text { sartadimana wae }\end{array}$ & - & $\sqrt{ }$ & - \\
\hline Ngajaga daya tahan awak & - & $\sqrt{ }$ & - \\
\hline $\begin{array}{l}\text { Moyan isuk-isuk salila 5-15 menit 2-3 kali } \\
\text { saminggu }\end{array}$ & - & $\sqrt{ }$ & - \\
\hline $\begin{array}{l}\text { Rutin olahraga sakurang-kurangna } 30 \\
\text { menit unggal poe }\end{array}$ & - & $\sqrt{ }$ & - \\
\hline Nginum cai herang \pm 2 liter unggal poe & - & $\sqrt{ }$ & - \\
\hline Sare cukup 7-8 jam unggal poe & - & $\sqrt{ }$ & - \\
\hline $\begin{array}{l}\text { Ngadahar kadaharan sehat jeung gizi } \\
\text { saimbang }\end{array}$ & - & $\sqrt{ }$ & - \\
\hline $\begin{array}{l}\text { Nginum suplemen atawa pitamin luyu } \\
\text { jeung saran ti dokter }\end{array}$ & - & $\sqrt{ }$ & - \\
\hline Ngajaga daya tahan mental & - & $\sqrt{ }$ & - \\
\hline Rajin ibadah jeung ulah kaweur & - & $\sqrt{ }$ & - \\
\hline $\begin{array}{l}\text { Ngajaga hubungan hade jeung nu raket ka } \\
\text { lingkungan sabundereun }\end{array}$ & - & $\sqrt{ }$ & - \\
\hline Wijak milih beja & - & $\sqrt{ }$ & - \\
\hline
\end{tabular}

The data 'sing apal ka diri sorangan, sing apal ka musuh anjeun, and sing apal kana medan perang anjeun' have the same clause pattern with emphasis on the word 'sing apal'. The word 'sing apal' is an implicit form of the imperative which refers to the adjective 'careful'. The adjective has the meaning of 'trusting' positively related to security from oneself, the enemy or the problem being faced, and the situation and condition of a problem that is currently happening.

Meanwhile, the data 'ngungkulan Covid-19 and $k u$ cara paanggang, urang bisa ngurangan risiko katepaan' has a different clause pattern but the meaning is the same. The 'ngungkulan Covid-19' clause pattern contains a message on the word 'ngungkulan'. The word 'ngungkulan' is an imperative form which has an implicit declarative meaning to the adjective "victory". The adjective has the meaning of 'pleasure' which is positively related to the satisfaction of a stage of achievement. Other data, namely ' $k$ u cara paanggang, urang bisa ngurangan risiko katepaan' contains messages on the words 'paanggang' and 'ngurangan'. These words are imperative forms which have an implicit declarative meaning to the adjective 'infected'. The adjective has the meaning of 'pleasure' which is positively related to the satisfaction of a stage of achievement. 
The next data is 'mikanyaah diri sorangan and mikanyaah batur'. The two data have the same clause pattern with emphasis on the word 'mikanyaah'. The word 'mikanyaah' is an implicit form of the imperative which refers to the adjective 'care'. The adjective has the meaning of 'attraction' which is positively related to the satisfaction of a stage of achievement.

In addition, the data 'ulah padeukeut jeung saha wae sartadimana wae'. The data has an emphasis on the word 'ulah padeukeut'. The word 'ulah padeukeut' is an explicit form of imperative which refers to the adjective 'be careful'. The adjective has the meaning of 'mandatory' positively related to the safety of the person met and the place visited.

Some of the data have an emphasis on the duration and frequency of activities that readers of the $3 \mathrm{M}$ health protocol behavioral change guidelines need to do such as 'moyan isuk-isuk salila 5-15 menit 2-3 kali saminggu'; 'rutin olahraga sakurang-kurangna 30 menit unggal poe'; 'nginum cai herang \pm 2 liter unggal poe'; and 'sare cukup 7-8 jam unggal poe' The words 'moyan isuk-isuk, rutin olahraga, nginum cai and sare cukup' have the same emphasis on the description of the duration and frequency of activity such as '2-3 kali seminggu, 30 menit unggal poe, \pm 2 liter unggal poe, and 7-8 jam unggal poe'. These words are an explicit form of the imperative which refers to the adjective "discipline". The adjective has the meaning of 'focusing' on the health of each individual by carrying out activities of a certain duration.

Meanwhile, the clauses 'ngadahar kadaharan sehat jeung gizi saimbang' and 'nginum suplemen atawa pitamin luyu jeung saran ti dokter'. The two data have a sentence pattern with an emphasis on the words 'ngadahar' and 'nginum'. The words 'ngadahar' and 'nginum' are imperative forms which have an implicit declarative meaning to the adjective "guaranteed". The adjective has the meaning of 'safety' which is positively related to the suitability of food and vitamin consumption for the community.

The next data is 'maintaining crew endurance', 'ngajaga daya tahan awak', 'ngajaga daya tahan mental and ngajaga hubungan hade jeung nu raket ka lingkungan sabundereun'. The data has the same clause pattern with the emphasis on the word 'ngajaga'. The word 'ngajaga' is an explicit form of the imperative which refers to the adjective 'careful'. The adjective has the meaning of 'mandatory' positively related to the safety of the immune system, mental endurance, and the relationship between human beings and the surrounding environment.

The data 'rajin ibadah jeung ulah kaweur and wijak milih beja' have a clause pattern that has the same meaning. The clauses 'rajin ibadah jeung ulah kaweur and wijak milih beja' are imperative forms which have an implicit declarative meaning to the adjective "attention". The adjective has the meaning of 'interest' in a positive way related to worship, panic, and the selection of information about Covid-19.

\section{Judgement}

In addition to the affective subsystem, this guideline contained the judgment subsystem. Judgement related to resources for judging behavior according to various normative principles and attitudes towards behavior that we admire or criticize, praise or curse, including two things, namely social esteem and social sanctions. The author classified the research data according to the meaning indicators in the table below:

\begin{tabular}{lcc}
\multicolumn{3}{c}{$\begin{array}{c}\text { Table 2. } \\
\text { Judgement }\end{array}$} \\
\cline { 2 - 4 } Clauses & \multicolumn{3}{l}{ Judgement } \\
\hline Sing apal ka diri sorangan & Social Esteem & Social Sanction \\
Sing apal ka musuh anjeun & $\sqrt{ }$ & - \\
Sing apal kana medan perang anjeun & $\sqrt{ }$ & - \\
Ngungkulan Covid-19 & $\sqrt{ }$ & - \\
Mikanyaah diri sorangan & $\sqrt{ }$ & - \\
Mikanyaah batur & $\sqrt{ }$ & - \\
\hline
\end{tabular}




\begin{tabular}{|c|c|c|}
\hline \multirow{2}{*}{ Clauses } & \multicolumn{2}{|c|}{ Judgement } \\
\hline & Social Esteem & Social Sanction \\
\hline $\begin{array}{l}\text { Ku cara paanggang, urang bisa ngurangan risiko } \\
\text { katepaan }\end{array}$ & $\sqrt{ }$ & - \\
\hline Ulah padeukeut jeung saha wae sartadimana wae & $\sqrt{ }$ & - \\
\hline Ngajaga daya tahan awak & - & $\sqrt{ }$ \\
\hline $\begin{array}{l}\text { Moyan isuk-isuk salila 5-15 menit 2-3 kali } \\
\text { saminggu }\end{array}$ & $\sqrt{ }$ & - \\
\hline $\begin{array}{l}\text { Rutin olahraga sakurang-kurangna } 30 \text { menit } \\
\text { unggal poe }\end{array}$ & $\sqrt{ }$ & - \\
\hline Nginum cai herang \pm 2 liter unggal poe & $\sqrt{ }$ & - \\
\hline Sare cukup 7-8 jam unggal poe & $\sqrt{ }$ & - \\
\hline Ngadahar kadaharan sehat jeung gizi saimbang & $\sqrt{ }$ & - \\
\hline $\begin{array}{l}\text { Nginum suplemen atawa pitamin luyu jeung } \\
\text { saran ti dokter }\end{array}$ & $\sqrt{ }$ & - \\
\hline Ngajaga daya tahan mental & - & $\sqrt{ }$ \\
\hline Rajin ibadah jeung ulah kaweur & $\sqrt{ }$ & - \\
\hline $\begin{array}{l}\text { Ngajaga hubungan hade jeung nu raket ka } \\
\text { lingkungan sabundereun }\end{array}$ & - & $\sqrt{ }$ \\
\hline Wijak milih beja & $\sqrt{ }$ & - \\
\hline
\end{tabular}

The data 'sing apal ka diri sorangan, sing apal ka musuh anjeun, and sing apal kana medan perang anjeun' showed the capacity through the word 'sing apal'. The capacity conveyed through the word is a social award related to the ability of each individual to regulate the pattern of one's own life, the enemy or problem being faced, and the situation and condition of a problem that is currently happening.

Meanwhile, the data on 'ngungkulan Covid-19 and ku cara paanggang, urang bisa ngurangan risiko katepaan' showed capacity through the words 'ngungkulan' and 'ngurangan'. The capacity conveyed through this word is a social award related to one's ability to deal with Covid-19 and the risk of transmission.

The next data is 'mikanyaah diri sorangan and mikanyaah batur'. The two data showed politeness through the word 'mikanyaah'. Politeness conveyed through these words is a social sanction related to concern for taking care of each other, both for oneself and for others.

In addition, the data 'ulah padeukeut jeung saha wae sartadimana wae'. The data showed capacity through the word 'ulah padeukeut'. The capacity conveyed through these words is a social award related to the ability of each individual to manage distance and interaction with fellow humans and the surrounding environment.

Some data show persistence such as 'moyan isuk-isuk salila 5-15 menit 2-3 kali saminggu'; 'rutin olahraga sakurang-kurangna 30 menit unggal poe'; 'nginum cai herang \pm 2 liter unggal poe'; and 'sare cukup 7-8 jam unggal poe'. The persistence conveyed through these clauses is a social reward related to the firm way of carrying out several activities to maintain the health of each individual.

Meanwhile, the clauses 'ngadahar kadaharan sehat jeung gizi saimbang' and 'nginum suplemen atawa pitamin luyu jeung saran ti dokter'. The two data showed capacity through the words 'ngadahar' and 'nginum'. The capacity conveyed through these words is a social award related to one's ability to manage portions of healthy food and balanced nutrition as well as vitamin consumption as directed by a doctor.

The next data is 'ngajaga daya tahan awak', 'ngajaga daya tahan mental and ngajaga hubungan hade jeung nu raket ka lingkungan sabundereun'. The data showed politeness through the word 'ngajaga'. Politeness conveyed through these words is a social sanction related to concern for endurance, mental endurance, and relationships between fellow humans and the surrounding environment. 
The data 'rajin ibadah jeung ulah kaweur and wijak milih beja' showed capacity. This capacity is a social award related to one's ability to carry out worship, divert panic, and select information about Covid-19.

\section{Appreciation}

This guideline contained the appreciation subsystem. Appreciation is related to mental processes (the way we view things) through reaction, composition and valuation. The authors classified the research data according to the meaning indicators in the table below:

Table 3.

Appreciation

\begin{tabular}{|c|c|c|c|}
\hline \multirow{2}{*}{ Clauses } & \multicolumn{3}{|c|}{ Appreciation } \\
\hline & Reaction & Composition & Valuation \\
\hline Sing apal ka diri sorangan & - & $\sqrt{ }$ & - \\
\hline Sing apal ka musuh anjeun & - & $\sqrt{ }$ & - \\
\hline Sing apal kana medan perang anjeun & - & $\sqrt{ }$ & - \\
\hline Ngungkulan Covid-19 & $\sqrt{ }$ & - & - \\
\hline Mikanyaah diri sorangan & - & - & $\sqrt{ }$ \\
\hline Mikanyaah batur & - & - & $\sqrt{ }$ \\
\hline $\begin{array}{l}\text { Ku cara paanggang, urang bisa ngurangan } \\
\text { risiko katepaan }\end{array}$ & $\sqrt{ }$ & - & - \\
\hline $\begin{array}{l}\text { Ulah padeukeut jeung saha wae sartadimana } \\
\text { wae }\end{array}$ & - & $\sqrt{ }$ & - \\
\hline Ngajaga daya tahan awak & - & - & $\sqrt{ }$ \\
\hline $\begin{array}{l}\text { Moyan isuk-isuk salila 5-15 menit 2-3 kali } \\
\text { saminggu }\end{array}$ & - & $\sqrt{ }$ & - \\
\hline $\begin{array}{l}\text { Rutin olahraga sakurang-kurangna } 30 \text { menit } \\
\text { unggal poe }\end{array}$ & - & $\sqrt{ }$ & - \\
\hline Nginum cai herang \pm 2 liter unggal poe & - & $\sqrt{ }$ & - \\
\hline Sare cukup 7-8 jam unggal poe & - & $\sqrt{ }$ & - \\
\hline $\begin{array}{l}\text { Ngadahar kadaharan sehat jeung gizi } \\
\text { saimbang }\end{array}$ & - & $\sqrt{ }$ & - \\
\hline $\begin{array}{l}\text { Nginum suplemen atawa pitamin luyu jeung } \\
\text { saran ti dokter }\end{array}$ & - & $\sqrt{ }$ & - \\
\hline Ngajaga daya tahan mental & - & - & $\sqrt{ }$ \\
\hline Rajin ibadah jeung ulah kaweur & - & $\sqrt{ }$ & - \\
\hline $\begin{array}{l}\text { Ngajaga hubungan hade jeung nu raket ka } \\
\text { lingkungan sabundereun }\end{array}$ & - & - & $\sqrt{ }$ \\
\hline Wijak milih beja & - & $\sqrt{ }$ & - \\
\hline
\end{tabular}

The data 'sing apal ka diri sorangan, sing apal ka musuh anjeun, and sing apal kana medan perang anjeun' showed balance through the word 'sing apal'. The balance conveyed through the word is a composition related to the logic of each individual in regulating the pattern of one's own life, the enemy or problem being faced, and the situation and condition of a problem that is currently happening.

Meanwhile, the data on 'ngungkulan Covid-19 and ku cara paanggang, urang bisa ngurangan risiko katepaan' showed the impact through the words 'ngungkulan' and 'ngurangan'. The impact conveyed through these words is a form of enthusiasm related to selfreaction in dealing with Covid-19 and the risk of transmission.

The next data is 'mikanyaah diri sorangan and mikanyaah batur'. The two data showed appreciation through the word 'mikanyaah'. The appreciation conveyed through these words is a form of cognition related to the consideration to take care of each other, both the condition of oneself and others.

In addition, the data 'ulah padeukeut jeung saha wae sartadimana wae'. The data showed balance through the word 'ulah padeukeut'. The balance conveyed through these words is a composition related to the logic of each individual in managing distance and interactions with fellow humans and the surrounding environment. 
Some data show a balance such as 'moyan isuk-isuk salila 5-15 menit 2-3 kali saminggu'; 'rutin olahraga sakurang-kurangna 30 menit unggal poe'; 'nginum cai herang \pm 2 liter unggal poe'; and 'sare cukup 7-8 jam unggal poe'. The balance conveyed through these clauses is a composition related to the logic of each individual in carrying out several activities to maintain health.

Meanwhile, the clauses 'ngadahar kadaharan sehat jeung gizi saimbang' and 'nginum suplemen atawa pitamin luyu jeung saran ti dokter'. The two data showed balance through the words 'ngadahar' and 'nginum'. The balance conveyed through these words is a composition related to the logic of each individual in regulating the portion of healthy food and balanced nutrition and vitamin consumption as directed by the doctor.

The next data is 'ngajaga daya tahan awak', 'ngajaga daya tahan mental and ngajaga hubungan hade jeung nu raket ka lingkungan sabundereun'. The data showed appreciation through the word 'ngajaga'. The award conveyed through the word is a form of cognition related to considerations of endurance, mental endurance, and the relationship between fellow humans and the surrounding environment.

The data 'rajin ibadah jeung ulah kaweur and wijak milih beja' showed balance. This balance is a composition related to the logic of each individual in carrying out worship, diverting panic, and choosing information about COVID-19.

Table 4.

Attitudinal Meaning

Attitudinal Meaning of Covid-19 Local Language Guidelines in West Java Province

\begin{tabular}{ccc|cc}
\hline & Attitude Subsystem & & \multicolumn{2}{c}{ Attitudinal Meaning } \\
\hline Affect & Judgement & Appreciation & Positive & Negative \\
\hline Security (15) & Social Esteem (16) & Composition (12) & $\sqrt{ }$ & - \\
Satisfaction (4) & Social Sanction (3) & Valuation (5) & $\sqrt{ }$ & - \\
Happiness (0) & - & Reaction (2) & $\sqrt{ }$ \\
\hline
\end{tabular}

Based on the results of the analysis and discussion of each research data, the authors found 15 clauses included in the affective indicator of the attitude subsystem in security meaning and 4 clauses satisfaction meaning. In addition, the authors found 16 clauses included in the attitude subsystem of judgment indicator referring to social esteem and 3 clauses referring to social sanction. The author also found 12 clauses included in the attitude subsystem of appreciation indicator referring to composition, 5 clauses referring to valuation, and 2 clauses referring to reaction. The results of the analysis of each clause listed in the $3 \mathrm{M}$ health protocol behavioral change guidelines, the authors conclude that the message conveyed is positive for the society.

\section{CLOSING}

Based on the results of the analysis and discussion conducted in research related to the behavioral change guidelines for the $3 \mathrm{M}$ health protocol, the authors conclude as followed: First, the attitude subsystem with affective indicators is dominated by 15 clauses in security meaning and 4 clauses in satisfaction meaning. This dominance showed the existence of trust through the behavior of 'trusting' and 'mandating' with regard to the safety affect listed in the guidelines. In addition, the guidelines contained a satisfying affect which is indicated by the presence of interest and pleasure through "attentive" and "praise" behavior. These behaviors showed positive meanings that are appropriate for the society to carry out as an effort to prevent the transmission of COVID-19 in Indonesia. Second, the attitude subsystem with judgment indicators is dominated by 16 clauses referring to social esteem and three clauses referring to social sanction. The dominance showed the capacity and persistence as a form of social esteem in the guidelines. In addition, the guidelines showed the existence of politeness as a form of social sanction. These behaviors showed positive meanings that are appropriate for the society 
to carry out as an effort to prevent the transmission of COVID-19 in Indonesia. Third, the attitude subsystem with appreciation indicator is dominated by 12 clauses referring to composition, five clauses referring to valuation, and two clauses referring to reaction. This dominance showed the existence of balance as the composition form in these guidelines. In addition, the guidelines showed the existence of consideration as the valuation form. Meanwhile, 2 clauses that refer to the reaction form are indicated by the presence of enthusiasm as a result of the implementation of these guidelines. These behaviors showed positive meanings that are appropriate for the community to carry out as an effort to prevent the transmission of COVID-19 in Indonesia.

\section{BIBLIOGRAPHY}

Bloom, K. \& Argamon, S. (2010). Automated Learning of appraisal extraction patterns. CorpusLinguistic Applications: Current Studies New Directions, 249-260. https://doi.org/10.1163/9789042028012_017

Caraka. (2020). Impact of COVID-19 large scale restriction on environment and economy in Indonesia. Global Journal of Environmental Science and Management. Special Issue COVID-19 Case Study.

Ding, A. (2017). The Analysis of Attitudinal Resources in Obama's Victory Speech from Perspective of Appraisal Theory. Higher Education of Social Science, 12(1).

Don, A. (2021). An introduction to theme issue: Systemic functional linguistics and appraisal analysis: Recent contributions to English language research. Journal of Research in Applied Linguistics, 12(2), 3-5.

Eggins, S. (2004). An Introduction to Systemic Functional Linguistics. Pinter.

Fontaine, L. et al. (2013). Systemic Functional Linguistics: Exploring Choice. Cambridge University Press. https://doi.org/10.1017/CBO9781139583077

Martin, J.R. and Rose, D. (2003). Working with Discourse: Meaning Beyond the Clause. Continuum.

Martin, J. . \& P. R. . W. (2005). The Language of Evaluation, Appraisal in English. Palgrave.

Moleong, L. (2002). Metodologi Penelitian Kualitatif. PT Remaja Rosdakarya.

Ross, A. S. and D. C. (2019). 'Going negative': An appraisal analysis of the rhetoric of Donald Trump on Twitter. Language and Communication Journal, 70. https://doi.org/10.1016/j.langcom.2019.09.003

Wiratno, T. (2018). Pengantar Ringkas Linguistik Sistemik Fungsional. Pustaka Pelajar.

Yuliana. (2020). Corona Virus Diseases (Covid-19): Sebuah Tinjauan Literatur. Wellness and Healthy Magazine, 187-192. https://doi.org/10.30604/well.95212020

Zaidi, A., \& W. P. R. . (2021). Attitudinal positioning and journalistic commentary in politically fraught circumstances: Editorializing about the killing of Osama bin Laden. Journal of Research in Applied Linguistics, 12(2), 89-102. 